\title{
ÚČINNÉ KOGNITIVNĚ BEHAVIORÁLNÍ POSTUPY PŘI LÉČBĚ PACIENTA SE ZÁVISLOSTÍ NA NÁVYKOVÝCH LÁTKÁCH: KAZUISTICKÉ SDĚLENÍ
}

\author{
Lenka Slámová
}

\begin{abstract}
Abstrakt
Daniel (32 let), v anamnéze dlouhodobé užívání kombinací návykových látek, nejčastěji marihuany, pervitinu, heroinu a alkoholu. Návykové látky začal užívat zhruba od 15 let z důvodu pozitivní rodinné anamnézy, vztahových a osobnostních problémů. Psychoterapeuticky jsme spolu pracovali během jeho trř́měsíční toxirehabilitační léčby $\mathrm{v}$ Psychiatrické nemocnici $\mathrm{v}$ Kroměřiží. Jméno pacienta bylo v kazuistice změněno. Daniel spolu s dalšími spolupacienty se podíleli na vytvoření programu a následně brožury pro pacienty s drogovou kariérou s kognitivně behaviorálními terapeutickými postupy. V terapeutickém cíli Daniela dominují témata bažení, jeho osobnostní nastavení, učení se sebeovládání: odmítání drogy, komunikace, práce se vztekem, nácvik relaxace, kognitivní vyhýbání se návykové látce, řešení problémů, prevence relapsu.
\end{abstract}

Klíčová slova: KBT; vznik závislostního chování; práce s jádrovým schématem; střednědobá léčba závislostí; katamnéza

\section{EFFECTIVE COGNITIVE - BEHAVIOURAL TECHNIQUES FOR TREATING A PATIENT ADDICTED ON DRUGS AND ALCOHOL: CASE HISTORY}

\begin{abstract}
Daniel (32 years old), with an anamnesis of long-term using of addictive substances, more precisely a combination of marihuana, methamphetamine, heroin and alcohol. He started taking addictive substances approximately at the age of 15 because of a positive family anamnesis, relationship and personal problems. From the psychotherapist's perspective we worked together during his tree-month toxinrehabilitation treatment in the psychiatric hospital in Kromeriz. The patient's name has been changed in case history. Daniel, together with other patients contributed to the creation of a programme and afterwards a brochure for patients with drugs career, based on cognitive - behavioural therapist techniques. Daniel's therapeutic goals are dominated by craving themes, his personality settings, learning self-control: drug rejection, communication, work with rage, relaxation training, cognitive avoidance with addictive substance, problem solving, and relapse prevention.
\end{abstract}

Key words: CBT; origin of addictive behaviour; work with the core scheme; middle-term treatment of additions; catamnesis

Došlo: 21. 2. 2018

Schváleno: 25. 6. 2018 


\section{Úvod}

Na kazuistice Daniela bych ráda poukázala, že současný trend v kognitivně behaviorální terapii (dále jen KBT) v léčbě závislostí na návykových látkách nachází stále širší uplatnění. Přístupy s využitím KBT jsou součástí časných a krátkých intervencí, které se široce používají v tzv. první linii - v ordinaci praktického lékaře, $\mathrm{v}$ nízkoprahovém programu $\mathrm{v}$ terénu nebo $\mathrm{v}$ kontaktním centru. Jejich cílem je snížit nebo zastavit užívání návykových látek, omezit rizika a získat motivaci pro vyhledání specializované pomoci. Zaměřují se na motivaci, povzbuzují klienta k tomu, aby se problémem zabýval. Dále se zaměřují na uvědomění si rizikových situací, na zvýšení sebekontroly, sebepozorování a odhalení spouštěčů rizikového chování.

Do arzenálu terapeutických intervencí v KBT u pacientů závislých na drogách by mělo patřit zaměření na ovlivňování tělesných příznaků (relaxační techniky), chování, tj. práce s bažením po droze (craving), nácvik sociálních dovedností, strukturace dne, a kognitivních procesů, tj. práce s motivací, s negativními myšlenkami a s dysfunkčními schématy (Praško, Možný, Šlepecký a kol., 2007).

Lidé, stejně jako Daniel, berou drogy, protože chtějí ve svém životě něco změnit. Existuje několik důvodů, které mladí lidé uvedli pro své rozhodnutí brát drogy, např. zapadnout do kolektivu, uniknout od reality a odpočinout si, zahnat nudu, udělat něco dospěláckého, vzbouřit se, experimentovat. Myslí si, že drogy jsou řešení. Ale nakonec se z drog stane problém.

\section{KBT v léčbě závislostí}

Syndrom závislosti na návykových látkách se charakterizuje jako silná touha brát psychoaktivní látky, alkohol nebo tabák. Diagnostikovat závislost by se obvykle mělo pouze tehdy, pokud během jednoho roku došlo ke třem a více $\mathrm{z}$ následujících projevů:

1. silná touha nebo pocit puzení,

2. potíže v sebeovládání,

3. tělesný odvykací stav,

4. vyžadování vyšších dávek,

5. zanedbávání zájmů či jiných aktivit,

6. užívání, i když jsou již zjevné škodlivé následky (Nešpor, 2011).

KBT vysvětluje vznik a následné udržování závislosti na návykových látkách na základě teorie učení, např. klasického a operantního podmiňování, tak i sociálního učení, např. učení nápodobou. Dalším vlivem jsou faktory kognitivně proměnné a faktory prostředí. Výsledkem je závislost jako malaadaptivní forma způsobu života, tzn. malaadaptivní životní styl. Z tohoto se vytvářejí dysfunkční kognitivní schémata, která vedou ke zranitelnosti daného člověka. Takový člověk si vytváří kompenzační strategie, jak překonávat či vyrovnávat se s emoční či kognitivní zátěží určité situace. Pokud je tato kompenzační strategie pozitivní, tzn. že „droga splnila moje očekávání, uvolnil jsem se, cítím se lépe“, člověk začne tuto strategii využívat (Kalina, 2013).

U Daniela bylo vytvořeno a syceno přesvědčení zdůvodňující pokračování užívání drogy jakousi potřebou sociálního kontaktu. Patřit do nějaké party, být v ní oceňován, přijímán. Ztráta skvělé party, kdyby „nebral“, byla v té době pro něho nepřijatelná. 


\section{Anamnestické údaje o Danielovi}

\section{Rodinná anamnéza}

Daniel se narodil v roce 1980 do úplné rodiny. Má dva bratry, vychází s nimi dobře. Starší bratr pije a užívá drogy zhruba 15 let. Nikdy neměl zájem se léčit, ani vlastní role otce jej k tomu nepřiměla, má ročního syna. Mladší bratr chodí ještě na základní školu, s drogami neexperimentuje.

Matka pracuje jako dělnice, má základní vzdělání a Daniel ji charakterizuje jako s prudší až vznětlivou, neurotickou povahou. Také ji vnímá jako relativně přísnou. Otec je aktuálně dlouhodobě nezaměstnaný, je povoláním voják a vystudovaný inženýr. Charakterizuje jej jako klidného dobráka, ale ne moc schopného či úspěšného. Má dlouhodobý problém s alkoholem, nikdy se neléčil. Daniel jako chlapec vnímal „opít se“ jako něco normálního. Rodinu považuje za dysfunkční, často se hádali, vznikaly dlouhodobé neshody, které vyvrcholily jeho odchodem z domova v osmnácti letech. Důvodem hádek a neshod bylo otcovo a již i Danielovo pití, později také experimentování s drogami. Dalším důvodem byla neúměrná pracovní zátěž, kterou na ně kladli rodiče. Stavěli několik let rodinný dům, Daniel si připadal jako levná pracovní síla, neměl čas na koníčky a záliby.

\section{Osobní anamnéza}

V rodině nikdy nebyly vážné nemoci. V minulosti měl spirálovou zlomeninu nohy, po rvačce v hospodě. Cítí se fyzicky i psychicky zdráv. Jen občas má silný craving po alkoholu a drogách. Léčí se poprvé.

\section{Sociální anamnéza}

V dětství se Daniel několikrát stěhoval napříč republikou. Vystudoval střední ekonomickou školu s maturitou, ale pracoval převážně v gastronomii jako kuchař-číšník. Po dobu studia intenzivně pil a kouřil marihuanu. Občas také chodil za školu.

Většinu své pracovní kariéry trávil v Praze a ve Velké Británii. Kvůli nadměrné konzumaci alkoholu a drog ho několikrát z práce vyhodili. Po finanční stránce je však stabilní a zabezpečen. Aktuálně je nezaměstnaný. Dodnes využívá peněz našetřených ze zahraničí.

První vztah měl v 17 letech a trval dva roky. Partnerku opustil z důvodu její promiskuity, i když byl na ni závislý s bydlením. Později měl několik krátkodobých vztahů, zejména v období své pracovní vytíženosti (pobyt v zahraničí), také to kompenzoval prostitutkami. Nyní bydlí sám, vlastní byt $2+1$, je svobodný a bezdětný. Po léčbě se bude do svého bytu vracet.

\section{Drogová kariéra Daniela}

Alkohol poprvé pil v patnácti letech doma u rodičů, kde byl velmi pozitivní vztah k alkoholu. Líbil se mu „odplavující“ účinek při tenzi. Tento stav míval velmi příjemný. Tehdy se „chytil““ skupiny mladých lidí vyznávající anarcho-punk style. Měl provokující vizáž a celkovou image, zejména střihy vlasů. Vnímal to jako formu odporu vůči společnosti. Silně pili a užívali prŕírodní drogy (hlavně marihuanu a v sezóně lysohlávky), opovrhovali syntetickými drogami. V devatenácti letech však začal inklinovat $\mathrm{k}$ lidem navštěvující technoparty, kde volně přešel k syntetickým drogám (LSD, extáze, pervitin). Ve dvaadvaceti letech emigroval do Velké 
Británie, kde s užíáním alkoholu a drog pokračoval. Navíc dostal př́ležitost užívat další drogy jako kokain, crack, heroin, ketamin a jiné. Po návratu z Velké Británie po úraze cca jeden rok nepil, ale začal víc kouřit marihuanu, šňupat a kouřit pervitin, pak přešel na nitrožilní aplikaci. Opět utekl do Velké Británie, kde přestal s marihuanou a pervitinem, ale vrátil se k plným dávkám alkoholu a občas si zakouřil heroin a crack. Po šesti měsících dostal výpověd' z práce kvůli alkoholu a vrátil se zpět do ČR. Po návratu bydlel chvíli u rodičů, protože svůj byt stále pronajímal. Znovu se vrátil k alkoholu, marihuaně a pervitinu, ale nikdy už nitrožilně. Cítí se závislý na alkoholu od devatenácti let. Uvádí, že jen při silné dávce alkoholu a drogách je agresivní. Daniel má tedy velkou drogovou zkušenost, vyzkoušel psychomotorická stimulancia, halucinogeny i tlumivé látky. Většina $z$ těchto výše jmenovaných drog má významný potenciál pro vznik psychické i somatické závislosti. Konkrétně na pervitin vzniká silná psychická závislost, u alkoholu je silná psychická i somatická závislost (Kalina, 2015).

Prvním krokem léčby proto bývá účinné posilování motivace. Při posilování motivace se zdůrazňuje projevování respektu, naslouchání a komunikování porozumění (reflexivní naslouchání) (Höschl, Libiger, Švestka, 2002).

\section{Konceptualizace př́́padu Daniela - vyšetř̌ení v rámci KBT}

KBT závislostí zahrnuje několik základních úloh. V první řadě je důležité vybudovat fungující terapeutický vztah založený na spolupráci. Povzbuzovat motivaci pacienta ke změně chování. Zmapovat funkční analýzu současných problémů pacienta. Využívat kognitivně behaviorálních technik ve strukturovaném časovém uspořádání. Stanovit a vyhodnocovat navržené cíle. Na závěr vyhodnotit terapii a ukončit ji (Gregorová, 2010).

\section{Vyšetření v rámci $K B T$}

V rámci vyšetření, které se skládalo z pozorování, rozhovoru, behaviorální, kognitivní a funkční analýzy, byl Daniel komplexně vyšetřen. Byla zjištěna anamnéza, jeho historie a vývoj uživání návykových látek, zjištovala jsem další psychické obtíže, které se mohou i nemusí vztahovat k uživání návykových látek. Zjišt’ovala jsem motivaci, snažila jsem se o povzbuzování.

\section{Behaviorální analýza}

$\mathrm{Na}$ základě A-B-C modelu byly hledány faktory, které vedou ke vzniku závislého chování, identifikovány spouštěcí mechanismy užívání. Důkladně byly analyzovány okolnosti jeho uživání, mapovány faktory prostředí. Byly identifikovány rizikové situace. Zvláštní pozornost jsem věnovala bažení a Daniel si vše zaznamenával. Popisoval své chování v souvislosti s užíváním drogy: mapoval si své fyziologické reakce, emoce, chování při aplikaci, případně při abstinenčních příznacích, identifikoval si své automatické negativní myšlenky. Své chování si popisoval v dimenzích frekvence výskytu, jeho trvání a intenzity.

\section{Kognitivni analýza}

Snažila jsem se odkrývat jádrová přesvědčení, která Daniel přechovával o návykových látkách, o uživání a jeho význam pro život, o sobě a druhých, o pohledu na svět. Po odkrytí těchto myšlenkových procesů u něho došlo k přehodnocení názorů na užívání drogy. Kognitivní profil se skládal z informací o spouštěčích, přesvědčeních a automatických myšlenkách. 
Získané informace jsme použili k vysvětlení modelu závislosti, vytvoření bludného kruhu užívání návykové látky.

\section{Funkční analýza}

Na základě funkční analýzy se Daniel snažil porozumět, jakou funkci má problém s uživáním drog v jeho životě a jaké faktory ho udržovaly nebo modifikovaly.

Na závěr vyšetření jsme stanovili spolu s Danielem předběžnou formulaci problému, stanovili jsme cíle a léčebný plán vedoucí k jejich dosahování. V terapeutickém plánu Daniela dominovala témata bažení, jeho osobnostní nastavení, učení se sebeovládání: odmítání drogy, asertivita a komunikace, práce se vztekem, nácvik relaxace, kognitivní vyhýbání se návykové látce, řešení problémů, prevence relapsu.

\section{Stanovené terapeutické cíle}

1. Terapie byla zaměřena na snížení intenzity přetrvávajících neprŕíjemných pocitů úzkosti, strachu, tenze, které ho výrazně omezovaly v plnění běžných denních úkolů, a na zvládání afektivních stavi̊ jako je agrese a vztek.

2. Uvědomovala jsem si, jak je pro něj důležitý kvalitní terapeutický vztah. Zaměřila jsem se také na udržování nabyté důvěry.

3. Terapie byla zaměřená na snížení negativních pocitů pomocí relaxačních imaginačních technik. Cílem bylo osvojit si i některé relaxační techniky jako je progresivní relaxace či autogenní trénink a nácvik kontrolovaného zklidňujícího dýchání.

4. Kognitivní terapie byla $\mathrm{v}$ jeho př́ipadě klíčová, s cílem zaměřit se na hledání a korekci automatických negativních myšlenek, spouštěčů bažení, jádrových schémat, které udržují jeho negativní postoj k sobě samému, rodičům a pozitivní postoj k návykové látce.

\section{Konkrétní terapeutický postup}

1. Psychoedukace - orientace $\mathrm{v}$ problému a edukace o závislosti zejména zaměření na emoční oblast - pocity viny, nervozita, úzkost, vztek atd. Provedení vstupních měření pomocí základních dotazníků, např. Beckův inventář úzkosti, Dotazník strachů, Beckův depresivní inventář a další koláč viny, teploměr pocitů vzteku apod.

2. Kognitivní restrukturalizace - identifikace a zkoumání pravdivosti automatických negativních myšlenek a jejich nahrazení vyváženými alternativními myšlenkami.

3. Práce s kognitivními schématy - identifikace a zkoumání jádrových přesvědčení a hledání konstruktivnějšího pohledu.

4. Nácvik relaxačních a dechových technik.

5. Nácvik sociálních dovedností - komunikace zaměřená na odmítání drogy, zvládání selhání a relapsu, vztahová komunikace (komunikace s nejbližšími, navázání nových vztahů s ,„čistými““ lidmi.

6. Řešení problémů - zaměření na vztahové problémy (vztah matka-Daniel, otec-Daniel) (Praško, Možný, Šlepecký a kol., 2007). 


\section{Konkrétní účinné postupy KBT při práci s Danielem}

KBT je psychoterapeutický směr, který se dynamicky rozvíjí a proměňuje. Rozvíjí se zejména v kognitivní oblasti, zjišt'ují se „vnitřni““ psychické procesy (jádrová přesvědčení), tím se výrazně přibližila psychodynamickým směrům. Kognitivně behaviorální terapie se snaží přizpůsobit individuálním potřebám konkrétního pacienta. Důležitý je vztah mezi terapeutem a pacientem, měl by být důvěrný. Základem terapeutického vztahu v KBT je otevřená aktivní spolupráce (Praško, Možný, Šlepecký, 2007).

\section{KBT a analýza problému (tzv. bludný kruh)}

Po provedení vyšetření a sběru anamnestických dat, kdy už jsme o problému věděli více, informace jsme dále uspořádávali a analyzovali do tzv. bludného kruhu (viz tabulka1). Daniel byl edukován o jednotlivých položkách, které tvoří bludný kruh potíží. Poté si sám snažil mapovat, jak jeho prožívání vypadá v různých situacích, a tak lépe pochopil, co se s ním děje (Slámová, 2012).

Tab. 1 Př́klad bludného kruhu Daniela

\section{Spouštěče}

Nečinnost - nemám režim, nemám práci, spoustu volnýho času...nuda, poflakování v posteli

\section{Myšlenky}

Nemám motivaci, kterým směrem mám jít, co mám udělat, jaká je správná cesta, jsem asi debil, když to zvládne i 15-ti leté ditě, jsem nevyužitelný, jsem neschopný, jsem hloupej, měl bych být dokonalý, dobrým člověkem, dobrým partnerem, dobrým otcem...nechci to ted' rešit, nechci nad tím ted" přemýšlet...ted' si ujedu, povznesu se nad tu situaci, chci se uvolnit, chci se uklidnit, neumím se rozhodnout, nechci se pro něco rozhodovat, nechci se vỉbec rozhodovat, bojím se rozhodnutí, bojím se zodpovédnosti...mám to všechno v paži...chci se nastřelit...chci drogu

\section{Emoce}

pocity prázdnoty, vztek na sebe, pocity nejistoty, rozmrzelost, úzkost, strach, tenze, nervozita, podrážděnost, pocity viny, sebelítost

\section{Tělesné reakce}

třes celého těla, bušení srdce, hučení v hlavě, cukání v těle, bolest celého těla, nauzea, kroucení těla, zvracení 


\begin{tabular}{|c|c|c|}
\hline \multicolumn{3}{|c|}{ 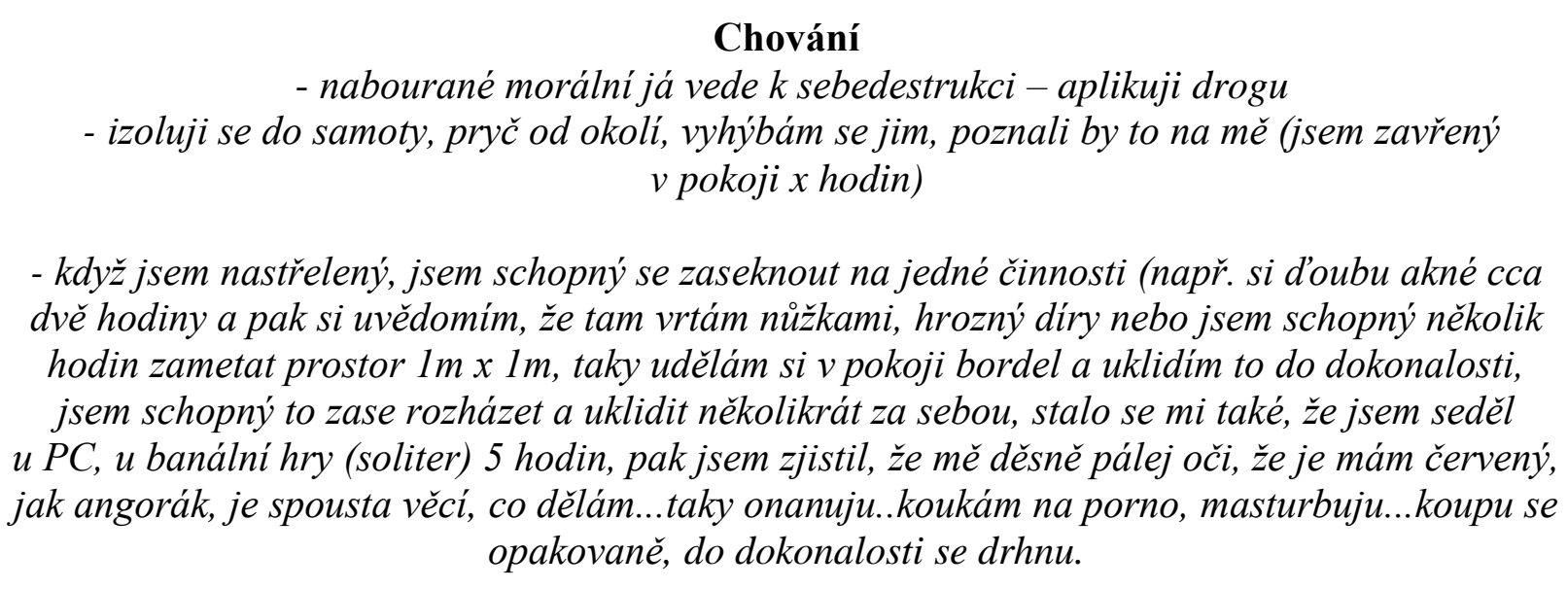 } \\
\hline Důsledky krátkodobé & $\begin{array}{l}\text { + úleva, pocit euforie, pocit } \\
\text { bezstarostnosti, problém už není } \\
\text { takovým problémem, dostatek } \\
\text { energie „životabudič“, zábava }\end{array}$ & $\begin{array}{l}\text { - podrážděnost, agresivita, } \\
\text { hádavost }\end{array}$ \\
\hline Důsledky dlouhodobé & $\begin{array}{l}\text { + dobrý pocit, že hodně věcí } \\
\text { stíhám, že hodně toho udělám, } \\
\text { nemusím u toho jíst, pít, spát - } \\
\text { funguji x hodin - nepřetržitě }\end{array}$ & $\begin{array}{l}\text { - mám stavy, že mé někdo sleduje } \\
\text { (paranoia), vyhýbám se lidem, } \\
\text { chci být jen sám s drogou, izoluji } \\
\text { se od okolí, depky, vyčerpání, } \\
\text { bolesti celého těla, třes }\end{array}$ \\
\hline
\end{tabular}

\section{KBT a práce s myšlenkami (tzv. kognitivní restrukturalizace)}

Postupně se učil zvládat mapovat své automatické negativní myšlenky (dále ANM), nacházet si vyváženější postoje $\mathrm{k}$ sobě, ke své životní situaci i vztahům v rodině. K tomuto posloužila i metoda kognitivní restrukturalizace (tzv. přerámování ANM), kterou si Daniel trénoval během celého léčebného pobytu. Byl edukován o tom, že právě myšlenky jsou zodpovědné za to, jak se cítí v dané situaci. Naučil se pracovat s myšlenkami konstruktivně, vytvářel si racionální/ alternativní myšlenky, které ho už neohrožovaly. 
Tab. 2 Záznam kognitivní restrukturalizace Daniela

\begin{tabular}{|c|c|c|c|c|c|c|}
\hline & $\begin{array}{l}\text { Emoce } \\
1-10\end{array}$ & Myšlenky & Co svědčí pro & $\begin{array}{l}\text { Co svědčí } \\
\text { proti }\end{array}$ & $\begin{array}{l}\text { Alternativní } \\
\text { myšlenka }\end{array}$ & $\begin{array}{l}\text { Emoce } \\
\text { nyní 1-10 }\end{array}$ \\
\hline $\begin{array}{l}27.6 . \\
\text { odpoledne } \\
\text { Nadal jsem } \\
\text { uklízečce do } \\
\text { piči, když mě } \\
\text { neposlechla po } \\
\text { opakované } \\
\text { výzvě, aby } \\
\text { opustila WC, } \\
\text { kde jsem konal } \\
\text { potřebu. } \\
\text { Dostal jsem } \\
\text { minusový bod. }\end{array}$ & $\begin{array}{l}\text { Vztek na } \\
\text { ni } 9 \\
\text { Vztek na } \\
\text { sebe } 10 \\
\text { Lítost } 9\end{array}$ & $\begin{array}{l}\text { Co sem leze, } \\
\text { kráva jedna. } \\
\text { Je úplně } \\
\text { vymaštěná, ona } \\
\text { mě snad } \\
\text { nerozumí. } \\
\text { Už toho mám } \\
\text { dost. Toto mě } \\
\text { vytáćí. } \\
\text { Je to piča. } \\
\text { To jsem neměl, } \\
\text { budu mít } \\
\text { problémy. } \\
\text { To jsem } \\
\text { nezvládl. } \\
\text { Nejsem vůbec } \\
\text { schopnej se } \\
\text { ovládat. } 95 \%\end{array}$ & $\begin{array}{l}\text { Když mě volá } \\
\text { matka, tak se } \\
\text { taky vytočím. } \\
\text { Některý z } \\
\text { pacientů, když } \\
\text { do mě ryje, } \\
\text { napálil bych } \\
\text { mu. } \\
\text { Sestry v noci } \\
\text { krákaly a smály } \\
\text { se dlouho do } \\
\text { noci, šel jsem } \\
\text { tam a jenom } \\
\text { soptil a nadával } \\
\text { anglicky - } \\
\text { fuck... atd. }\end{array}$ & $\begin{array}{l}\text { Ona ví, čím mě } \\
\text { může vytočit, ale } \\
\text { ted' to zvládám, } \\
\text { snažím se } \\
\text { kontrolovat. } \\
\text { Když jsem } \\
\text { fetoval, sprostě } \\
\text { jsem jí nadával, } \\
\text { ted' to vlastně } \\
\text { moc nedělám. } \\
\text { Na oddělení } \\
\text { jsem nikoho } \\
\text { neuhodil, hlídám } \\
\text { se. Vždycky si } \\
\text { řeknu, že bych } \\
\text { ublížil jen sám } \\
\text { sobě, zmařil } \\
\text { léčbu. Léčím se } \\
\text { pro sebe. A } \\
\text { umím si to } \\
\text { s nimi vyřídit i } \\
\text { slovně. Také } \\
\text { jsem to hlásil 1x } \\
\text { personálu. } \\
\text { Se sestrami } \\
\text { vycházím dobře, } \\
\text { v ten den jsem } \\
\text { byl nevyspalý, } \\
\text { měl jsem po } \\
\text { dovolence a } \\
\text { ještě na mě něco } \\
\text { lezlo. }\end{array}$ & $\begin{array}{l}\text { Jde vidět, že } \\
\text { přeháním, ve } \\
\text { většině př́ípadů } \\
\text { se snažím } \\
\text { kontrolovat své } \\
\text { emoce. Pracuji } \\
\text { na tom. } \\
\text { Vím, že začátky } \\
\text { jsou těžké, ale } \\
\text { pokroky dělám. } \\
\text { Uvědomuji si, } \\
\text { že jsem } \\
\text { impulzivní a že } \\
\text { drogou to jen } \\
\text { zintenzivním. } \\
\text { Přišel jsem si } \\
\text { také na to, že } \\
\text { když jsem } \\
\text { unavený nebo } \\
\text { nemocný, jsem } \\
\text { také více } \\
\text { podrážděný. } \\
98 \%\end{array}$ & $\begin{array}{l}\text { Vztek na ni } \\
5 \\
\text { Vztek na } \\
\text { sebe } 4 \\
\text { Lítost } 3\end{array}$ \\
\hline
\end{tabular}




\section{KBT a práce s jádrovými schématy}

Podle teorie KBT jsou zdrojem jednotlivých automatických myšlenek hlubší kognitivní struktury, které jsou označovány jako „schémata“. Tato „schémata“ si člověk vytváří během života již od raného dětství na základě svých zážitků a zkušeností. Jádrová přesvědčení jsou ustálený všeobecný způsob interpretace a hodnocení sebe, druhých lidí a světa okolo. Bývají většinou stabilní, nemění se každou událostí. Jsou nepodmíněná, znamená to, že platí za všech okolností a bývají rigidní, nikoli však zcela neměnná. Mohou se měnit vlivem asimilace a akomodace (upravuje se podle nových zkušeností). Postoje, které byly vytvořeny v dětství na základě negativních zkušeností, odrážejí zúžené negativní dětské porozumění situaci a bývají rigidní a nepřizpůsobivé. Pochopitelně ne u všech lidí, kteří byli v dětství vystaveni zátěžovým podmínkám, se později vyvine např. porucha osobnosti. Záleží rovněž i na vrozené zranitelnosti a odolnosti vůči psychotraumatům (Praško a kol., 2009).

Negativní schéma lze zpochybňovat jako každou negativní myšlenku pomocí různých metod kognitivní terapie. Jednou z možností, co si Daniel vyzkoušel, bylo, že hledal výhody a nevýhody svého škodlivého schématu, potom hledal jeho konstruktivnější pohled a co by to změnilo $\mathrm{v}$ jeho životě a co se proto musí naučit.

Tab. 3 Záznam práce s jádrovým přesvědčením Daniela

\begin{tabular}{|l|}
\hline \multicolumn{2}{|c|}{ Škodlivé přesvědčení: } \\
\multicolumn{2}{|c|}{ Abych zapadl do party (punková orientace), abych byl přijat, musím se chovat výstředně a neobvykle. } \\
Chovat se jako PAN NĚKDO!
\end{tabular}


Co by to změnilo v mém životě:

Byl bych spokojenější, klidnější sám se sebou. Nebyl bych v takovém stresu, měl bych čas sám na sebe, nejednal bych impulzivně - lépe se tak přijímá kritika a podřizuje druhým. Celkově by to mělo pozitivní dopad i na okolí, mohl bych tak navázat nějaký trvalejší vztah.

Co se proto musím naučit:

Toleranci, empatii, naslouchání, sebeovládání, umět se podř́ídit, přijímat kritiku

\section{KBT a práce s terapeutickými dopisy}

Psaní dopisů je jednou z důležitých zážitkových technik, která je určená k emocionální restrukturalizaci. Většinou jde o necenzurované dopisy, které zpravidla bývají v co nejsyrovější podobě. Jsou plné emocí, potřeb, nároků - pacient tak vlastně píše dopis osobám uvnitř sebe, těm osobám, které se minulosti podílely na vzniku jeho maladaptivních schémat nebo těm, které je v současnosti pomáhají udržovat (Praško, Možný, Šlepecký a kol., 2007).

Daniel vypracoval otevřený dopis matce. Několikrát dopis roztrhal, pak zase zkusil chvíli psát, ale nevydržel to. Bourrilo to v něm, vztekal se, vyčítal, plakal, byl lítostivý. Jednoho večera, kdy pacienti sledovali televizní program, Daniel na jeden ,zátah“ dopis napsal. Sdělil, že takovou úlevu a vnitřní klid už dlouho nezažil. Dal do toho všechno, pral se s každou myšlenkou, s každým pocitem - jak uvedl: „Všechno jsem tam „vyblil““. S jeho dopisem jsme dále pracovali, vybírali nejzranitelnější situace, odpovídali na položené otázky s cílem porozumět a emočně ukotvit jejich narušený vztah.

\section{Záznam terapeutického dopisu matce Daniela}

\section{Milá mami,}

musím ti ř́ct, že mezi punkáčema cejtil jsem se líp. Neměj mi to za zlé, ale věr mi, že sem pro to měl své důvody. Už v dětství jsem se necítil dobře ve tvé př́tomnosti. Aby ne, když se mi stále vybavuje, jak na mně a bráchu křičís. Dost často jsi nás také bila. Vybavuji si situaci, že jsem dostal bezdůvodně facku, jen proto, že jsi měla špatnou náladu. A ty jsi ji měla špatnou docela často. Já chápu, že jsi to v dětství i později měla těžké, ale to tě neopravňuje tyto chyby zopakovat a prenést do dalši generace. Později kolem mých 11 let, jste se rozhodli s otcem, že budete stavět dům. My jsme nechápali, že si o víkendech nemůžeme hrát a uživat si volného času. Místo hraček, jsme dostali do rukou krumpáče a lopaty...Nemyslíš si, že to zaváni trochu opiči láskou? Že si své potřeby upřednostňovala před potřebami svých dětí...3x jsme se museli $v$ dětstvi stěhovat napřič republikou. I to bylo poměrně dost vyčerpávajíci a stresující. Nová škola, nové prostredí, noví kamarádi...Když jsme dostavěli rodinný di̊m, tak jste začali s náma hospodařit na zděděném statku. Stali jsme se pro vás zase výhodnou levnou pracovní silou. Nikdy to zemédělství nevynášelo a pokud ano, aspoň z dotací, tak my s bráchou jsme z toho nikdy nic neviděli. Vždycky jste na nás šetřili. Šak sis to vždy nějak omluvila. To, že jsme pro tebe tvrdě pracovali, ti asi nebylo dost dobrý. Jinak si nedovedu vysvětlit, proč si na nás $k$ tomu ještě pořád 
křičela...Opravdu si myslišs, že jsme si to zasloužili? Jiné děcka se ve škole učily, já únavou na lavici spal...A po škole znova pracovat. Jiné děcka se těšily, až uvidí svou mámu odpoledne. Já se modlil, abys jednou už nepřišla. Nikdo by neměl bagatelizovat tyto pocity. Jestli ano, tak těmto lidem preju, aby to v dětství zažily...V 15-ti letech jsem objevil účinek alkoholu a marihuany. Víš, že jsem to bral už od mých 15-ti let? Umožňovalo mně to líp snášet tíživou rodinnou situaci. A punkáči? Mezi něma jsem byl někým...Doma jsem byl využivaný hadr na zem. Po střední škole jsem byl nezaměstnaný, ale podstatnou část podpory jsem ti dával, ještě k tomu vkuse pracoval. Ani to ti nebylo dost dobrý. Tak jsme s bráchou museli odejít z domova. Radši jsem bydlel u prostitutky než u tebe. Pravidelně poslouchala, jak na záchodě brečím. Od 18-ti let vkuse utíkám. Utíkám prèed něčím, co mě hravě kdykoliv a kdekoliv dohoní. Jsou to vzpomínky. Nikdy nepochopím tvoji strategii: „Dana nesmite nikdy chválit. “Věr mi, že spoustu let jsi pro mě byla zhmotnèné zlo. Až v prosinci 2010, když mě bylo 30 let, jsem ti v opilosti od srdce řekl, co si o tobě myslím. Rozbrečela ses a od té doby jsi mě dala pokoj. Konečně jsem se dokázal trochu volněji nadechnout. Pevně věř́m a doufám, že se jednou naše vztahy urovnají, ale minulost nejde vzít zpět. Já už nečekám, že se omluvíš. Já vlastně zapomněl, že se nemýlís. Když hledáš chybu, tak vždycky jenom $v$ druhých...

Dan

\section{KBT a práce s imaginací}

Další zážitkovou metodou v KBT je využití představivosti a rovněž se použivá k emocionální restrukturalizaci. Smyslem zážitkových technik je prožít si novou emoční korektivní zkušenost a umožnit propojení kognitivního porozumění s emocionálními stavy. Hlavním principem při vedení imaginace je používat co nejméně instrukcí. Klíčové je, aby ona představa byla skutečně pacientova a nikoliv vsugerovaná terapeutem. Terapeut ř́ká pouze obecné instrukce. Terapeut může pacientovi pomáhat různými otázkami. Terapeut do textu nejčastěji vkládá otázky: „Co nyní vidíte? Jaký je na vás pohled? Co cítíte? Co v tu chvíli nejvíce chcete? Co vás napadá? Co se děje ve vašem těle? Jaká byla pro vás tato zkušenost?“ (Praško, Možný, Šlepecký, 2007).

Terapeut pomáhá pacientovi prožít jeho představy co nejintenzivněji, aby se vynořily všechny důležité emoce. Po skončení imaginace pomáhá terapeut pacientovi uvědomit si tu skutečnost, co se dělo, rozebírají a napravují se jeho zkušenosti, představy, mohou se objevit i další témata pro další imaginaci.

V léčbě závislostí jsou využívány i řízené imaginace, kdy jsou pacientovi navrhovány určité obrazy, motivy či témata a mají sloužit zejména $\mathrm{k}$ sebezdokonalování se zaměřením na budoucnost, např. imaginace člověka, který pije nebo fetuje, nabídnutí drogy, silné bažení (Kratochvíl, 2002). Cílem imaginace u Daniela bylo zažít si v relaxovaném stavu představy jeho nepř́ijemných zážitků, konfliktů z období, kdy fetoval, a zaměřit se na změnu emočního doprovodu tohoto zážitku.

\section{Záznam řízené imaginace při skupinové relaxaci}

„Před vaším vnitřním zrakem se za chvili objevi obraz vás samotných. Ve svých představách jste po nějakém konfliktu nebo po nějakém nedorozumění, po nějakém neúspěchu nebo pádu. Možná býváte po takových událostech plný hněvu, možná jste naopak smutný a osamělý. Možná pocitujete výčitky svědomí. Tyto nepř́jemné pocity jsou tak silné, až jsou bolestivé. Mohou se vám zdát ǎ̌ nesnesitelné, nezvládnutelné. Představte si sami sebe v takové situaci. Pomalu, 
nejprve velmi slabě, pak víc a víc jasněji se před vaším vniťrním zrakem objevuje tento obraz. Stává se ale žretelnějším a žretelnějšim. Ve svých představách jste po nějakém konfliktu nebo po nějakém nedorozumění, po nějakém neúspěchu nebo pádu. Máte nepř́jemné, až bolestivé pocity. Chtěl byste něč́m tyto nepř́jemné pocity odstranit, zbavit se jich... Napadá vás, že jste $v$ minulosti $v$ takových situacich často přijal nějakou drogu, abyste se snad na krátký čas zbavil těchto nepř́jemných pocitũ. Tato představa užití drogy je velmi lákavá, cítite se jí být silně pritahován.

Současně vás však napadá, jaké by to bylo na dojezdu drogy. Přemýšlite o tom, že by př́činy vašich pocitů stejně zůstaly, že by vám droga nijak nepomohla, že by vám spiše dodala smutek, únavu, nejistotu, výčitky svědomí. V̌se by bylo na dojezdu ještě horší. Tento obraz dojezdu drogy ve vás pomalu vyvstává. I obraz toho, že byste se po takovém pádu musel za pomoci druhých pomalu zvedat, znovu budovat to, co jste ve své abstinenci dosáhl, znovu se učit ze svých chyb. Vyvstane ve vás obraz vašeho pocitového deníku a všeho, co jste v něm zmiňoval - obraz léçby, osob, se kterými jste se tam setkal. Tyto obrazy máte nyni před svým vnitřním zrakem.

Proto odvracite svou pozornost od myšlenek na drogu, jdete dělat něco, co vás baví, jdete se zapojit do nějaké činnosti, přitom přemýšlite, komu byste mohl zavolat, koho byste mohl navštívit. $S$ kým byste mohl hovořit. Snad i obraz těch, kterým byste vy sám mohl pomoci. Jdete se zapojit do nějaké činnosti.

Současně se ve vás brzy objeví nový pocit. Př́ijemný pocit. Budete rád, že jste tuto situaci zvládl bez drogy. Budete se sebou spokojen, že jste tuto situaci zvládl bez většího zaváhání. Již začínáte tento pocit cítit - pocit spokojenosti, př́iemnosti, pohody. Postupně se stáváte spokojenějši. Jste spokojený, že jste oné naléhavosti odolal. Máte radost, jste v pohodě. Roste ve vás odhodlání uskutečnit svoje životní plány. Celá tato událost se vám pevně vrývá do vaši paměti - to, co se dělo; to, co se mohlo stát, i ten dobrý pocit, který jste měl, když jste dokázal odolat. To vše se vám pevně vrývá do vaši paméti.

Zvolna ale rázně opouštite onu situaci. Směrujete tam, kde se cítite v bezpečí, v klidu, v pohodě. Směrujete opět do této mistnosti - kde se budete cítit v bezpečí, v klidu a v pohodě. Máte ze sebe dobrý pocit a jste na sebe hrdý. “

\section{Telefonická katamnéza po roce léčby}

Daniel byl hospitalizovaný na toxirehabilitačním oddělení $\mathrm{v}$ Psychiatrické nemocnici v Kroměříži, kde chtěl absolvovat komplexní tríměsíční léčbu. Jeho plány do budoucna byly takové, že po absolvování tríměsíční léčby se vrátí do svého bytu a najde si novou práci. Pokusí se o funkční partnerský vztah a o založení rodiny. Dále udělá vše pro trvalou abstinenci a bude v kontaktu s psychologem. Jako nejtěžší vnímal opustit rizikové prostředí (po patnácti letech braní drog a užívání alkoholu nikoho než fet’áky a alkáče nezná). Musí prorazit léty fixovaný toxikomanický životní stereotyp.

Při léčbě byl velmi aktivní, motivovaný a otevřený. Zaujal zodpovědný postoj a zapojil všechno své odhodlání jednou pro vždy skoncovat s návykovými látkami. Nad rámec svého terapeutického pobytu spolu ještě s dalšími spolupacienty založili „punk rockovou kapelu“ a vydali demo nahrávku. Léčbu úspěšně dokončil. Neměl dále zájem o doléčovací ani komunitní zařízení. Doléčovací zařízení poskytují chráněné prostředí na kratší dobu, naproti tomu terapeutické komunity jsou sociálním prostředím, které se vyznačuje organizovaností, strukturou a bezpečím. Jde o terapii s dlouhodobým úzdravným působením, kde se lidé každodenně 
setkávají, neustále reflektují, objasňují a konfrontují své vnitřní procesy (Kalina, 2008). Daniel byl přsesvědčený, že svou závislost zvládne, že ji porazil.

Dle telefonické konzultace po roce léčby bylo zjištěno, že doposud pravidelně dochází $\mathrm{k}$ doporučenému KBT terapeutovi $\mathrm{v}$ místě bydliště, navštěvuje velké A-kluby v naší nemocnici. Je zaměstnaný, bere to spíše jako zdroj př́imu, není tam možnost seberealizace. Opět začal cestovat, našel si „exotickou“ přítelkyni. Jednu zahraniční dovolenou absolvoval dokonce s matkou. Aktuálně je jeden rok a tři měsíce čistý.

\section{Závěr}

Do dnešní doby byly vytvořeny desítky programů, terapií a příruček, jejichž tvůrci se snažili podle svých teoretických východisek o ovlivnění užívání návykových látek $\mathrm{s}$ různou dávkou entuziasmu a ambicí. Nicméně lze konstatovat, že některé z nich se praxí a výzkumem ukázaly být vhodnější než jiné v léčbě konkrétní poruchy u specifické populace pacientů. Vnímám však $\mathrm{Z}$ vlastní zkušenosti větší důležitost $\mathrm{v}$ zaangažovanosti a připravenosti terapeuta, prvního kontaktu s pacientem a navození důvěrné atmosféry ve vztahu. Zjistila jsem také, že je vhodné i zapojit do terapeutického procesu osoby z pacientova okolí (probíhaly rozhovory s rodiči, partnerkami, manželkami apod.), věnovat se i př́ípadné komorbiditě (často duální diagnózy závislost v kombinaci s poruchou osobnosti, úzkostně depresivní poruchou, bipolárně afektivní poruchou apod.), neustále pracovat s motivací a poskytovat adekvátní zpětnou vazbu (Slámová, 2012).

Daniel aktivně spolupracoval, dodržoval termíny, plnil zadané úkoly. Byl za to velmi posilován a oceňován, což mělo také pozitivní vliv na jeho sebedůvěru a sebehodnotu. Věděl, že má velké problémy s návykovými látkami, první pocity úlevy se dostavily po opakované edukaci a společně provedené behaviorální, kognitivní a funkční analýze. Také se domnívám, že jsem byla trpělivá a nechávala jsem mu dostatečný prostor k vyjádření emocí, objasňovala a hledala s ním společně pro něj nejpřijatelnější způsoby. Terapii jsem se snažila vést empaticky, s pochopením, posilováním důvěry a dodávání emoční podpory. Pomohlo, že si opakovaně a v bezpečném prostředí vyzkoušel techniky vedoucí $\mathrm{k}$ lepšímu sebeovládání s následným rozborem, korekcí a nácvikem (zafixováním) nových vhodnějších způsobů reagování, ventilování emocí. Hlavní cíle psychoterapie byly splněny. Daniel se dokázal více ovládat, mít pod větší kontrolou emoce, zejména vztek. Práce s kognitivními schématy ho ovlivnilo v lepším sebepochopení, kdo je, kam směřuje, jak se vztahuje $\mathrm{k}$ lidem, zejména rodičům. Aktivně spolupracoval na konstruktivnějším sebepohledu. Osvojil si relaxační techniky jako je progresivní relaxace, zklidňující dech - vnímal zejména pozitivní tělesný efekt - svalové uvolnění. Sám považoval terapii jako dostačující, bylo však vhodné, dle délky jeho drogové kariéry, pokračovat $\mathrm{v}$ terapii ambulantní formou. 


\section{Literatura}

Gregorová, M. (2010). KBT alkoholismu. Nepublikovaná závěrečná práce ve výcviku v KBT. Höschl, C., Libiger, J., Švestka J. (2002). Psychiatrie. Praha: Tigis.

Praško, J. a kol. (2009). Poruchy osobnosti. Praha: Portál.

Praško, J., Možný, P., Šlepecký, M. (2007). Kognitivně behaviorální terapie psychických poruch. Praha: Triton.

Kratochvíl, S. (2002). Základy psychoterapie. Praha: Portál.

Slámová, L. (2012). „Mưj falešný přitel“ - droga. Nepublikovaná závěrečná práce ve výcviku v KBT.

Nešpor, K. (2011). Návykové chování a závislost. Praha: Portál.

Kalina, K. (2008). Terapeutická komunita - obecný model a jeho aplikace v léčbě závislosti. Praha: Grada.

Kalina, K. (2013). Psychoterapeutické systémy a jejich uplatnění v adiktologii. Praha: Grada. Kalina, K (2015). Klinická adiktologie. Praha: Grada.

\section{O autorce}

PhDr. Lenka Slámová vystudovala jednooborovou psychologii na Filozofické fakultě Univerzity Palackého v Olomouci a obor Speciální pedagogika na Pedagogické fakultě Masarykovy univerzity v Brně. Pracuje jako klinický a dopravní psycholog, psychoterapeut, jednak v Psychiatrické nemocnici v Kroměříži, ale také ve svém soukromém zdravotnickém zařízení v Moravské Třebové. Dokončuje doktorský studijní program v oboru Klinická psychologie na FF UP v Olomouci. Absolvovala pětiletý výcvik v kognitivně behaviorální terapii pod lektorským vedením prof. MUDr. Jána Pavlova Praška, CSc. a MUDr. Petra Možného. Z dalších terapeutických přístupů, které využívá ve své praxi, je klinická hypnoterapie. Tento kurz absolvovala pod vedením prof. PhDr. Stanislava Kratochvíla, CSc. Dále využívá podpůrnou terapii za asistence psa, tzv. canisterapii, kterou dlouhodobě aplikuje na odděleních Psychiatrické nemocnice v Kroměřiži, aktuálně na dětském psychiatrickém oddělení.

\section{Kontaktní údaje:}

Adresa: Psychiatrická nemocnice v Kroměříži, Havlíčkova 1265, 76740 Kroměříž; Ordinace klinické psychologie a dopravně psychologické centrum, Komenského 1662/50a, 57101 Moravská Třebová.

Email: slamoval@pnkm.cz; lenka.canis@seznam.cz

Slámová, L. (2018). Účinné kognitivně behaviorální postupy při léčbě pacienta se závislostí na návykových látkách: kazuistické sdělení. E-psychologie, 12(2), 41-54. https://doi.org./10.29364/epsy.315 